\title{
CORRIGENDUM
}

\section{Corticostriatal circuit defects in Hoxb8 mutant mice}

N Nagarajan, BW Jones, PJ West, RE Marc and MR Capecchi

Molecular Psychiatry advance online publication, 28 November 2017; doi:10.1038/mp.2017.251

Correction to: Molecular Psychiatry advanced online publication, 26 September 2017; doi: 10.1038/mp.2017.180

Following publication of the above article, the authors discovered that the $x$-axes of Figures $4 a-f$ and Supplementary Figure 7a were incorrectly labeled. The corrected figures appear below and as Supplementary Material to this corrigendum.

\begin{abstract}
cc) (i) (2) $\Theta$ This work is licensed under a Creative Commons Attribution(cc) ${ }_{\mathrm{BY}}$ NC No NonCommercial-NoDerivs 4.0 International License. The images or other third party material in this article are included in the article's Creative Commons license, unless indicated otherwise in the credit line; if the material is not included under the Creative Commons license, users will need to obtain permission from the license holder to reproduce the material. To view a copy of this license, visit http:// creativecommons.org/licenses/by-nc-nd/4.0/
\end{abstract}

(c) The Author(s) 2017

Supplementary Information accompanies the paper on the Molecular Psychiatry website (http://www.nature.com/mp) 

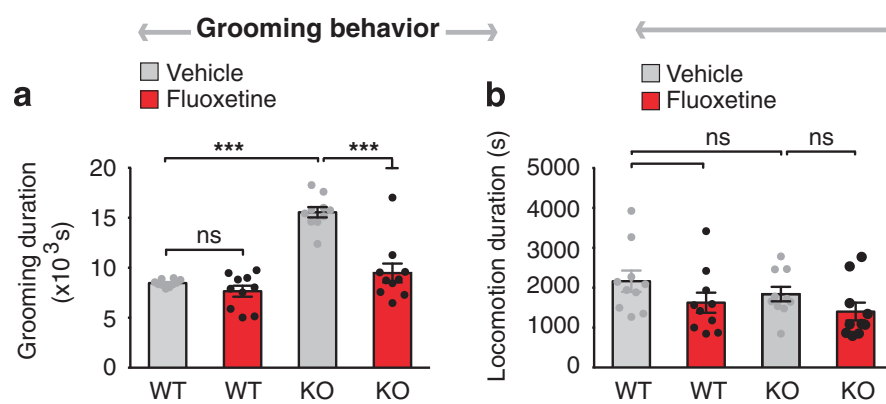

Non grooming behaviors

Anxiety behaviors

Open field

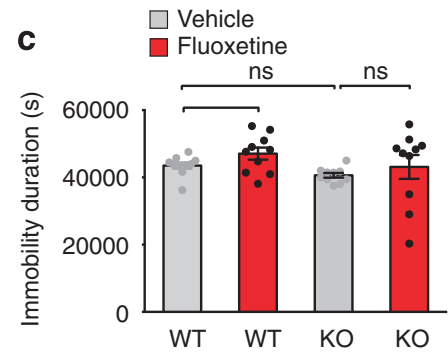

Plus maze

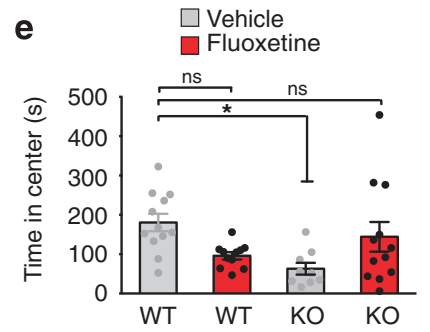

Light-dark test

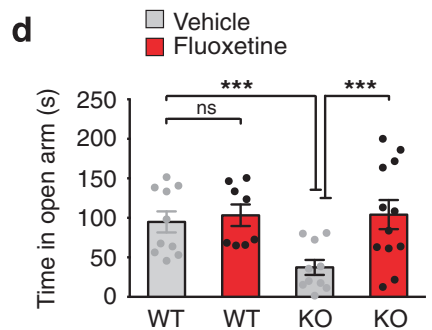

f $\square$ Vehicle

9
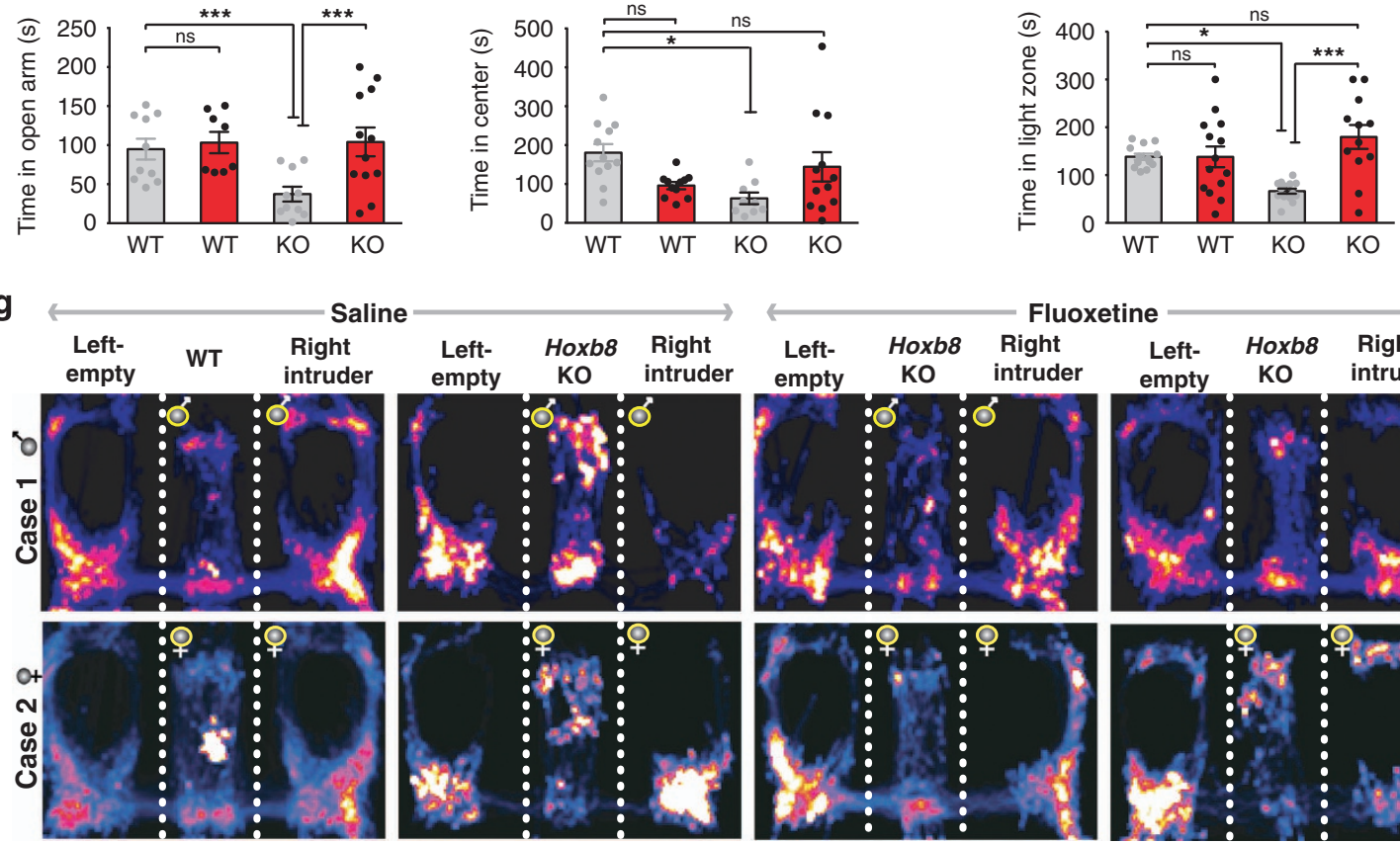

h

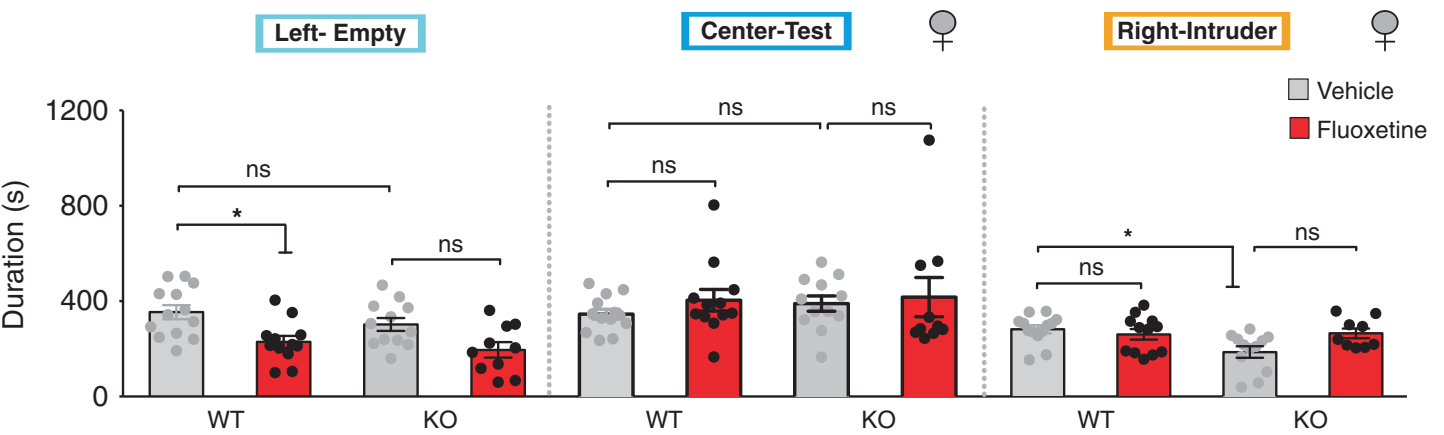

Figure 4. 